\title{
Interactions Between Xanthomonas campestris pv. graminis Strains and Meadow Fescue and Italian Rye Grass Cultivars
}

\author{
V. V. Michel, Swiss Federal Research Station for Plant Production of Changins, CH-1260 Nyon 1, Switzerland
}

\begin{abstract}
Michel, V. V. 2001. Interactions between Xanthomonas campestris pv. graminis strains and meadow fescue and Italian rye grass cultivars. Plant Dis. 85:538-542.

Eleven strains of Xanthomonas campestris pv. graminis, causal agent of grass bacterial wilt, collected over 20 years, varied significantly $(P<0.001)$ in their aggressiveness on meadow fescue and Italian rye grass. Aggressiveness of strains isolated since 1993 was not higher than strains isolated from 1975 to 1984 . Significant interactions $(P<0.001)$ between $X$. campestris pv. graminis strains and cultivars occurred for meadow fescue but not for Italian rye grass $(P=$ 0. 934). Inoculation with a single, highly aggressive strain for breeding of meadow fescue proved to be useful to increase the resistance to bacterial wilt, but improvement became stagnant after an initial strong increase in resistance level. Furthermore, a possible breakdown of the resistance of meadow fescue cultivars when grown in exotic environments might be possible. Therefore, the use of a strain mixture for breeding of meadow fescue is recommended.
\end{abstract}

Additional keywords: forage grass

Bacterial wilt caused by Xanthomonas campestris pv. graminis is a major disease in the majority of forage grass species cultivated in Central Europe (12). The disease was observed for the first time by researchers of the Swiss agricultural research system in the early 1970s (3). It is considered the main reason for shortened persistence of several important forage grass species in Switzerland, such as meadow fescue (Festuca pratensis), tall fescue (Festuca arundinacea), Italian rye grass (Lolium multiflorum), and perennial rye grass (Lolium perenne). The most susceptible species is Italian rye grass, for which annual yield losses of susceptible cultivars can reach 20\% (17). Despite the absence of seed transmission of the pathogen (7), the disease spreads easily to newly sown grasslands by means of the cutting devices used to harvest forage grasses $(7,14)$. The high harvest frequency of four to six cuts annually in most of the grassland areas and a prohibition against antibiotics in plant production in Switzerland exclude the use of chemicals for the control of grass bacterial wilt.

Resistance is the most important means to control bacterial wilt in Switzerland (15). Breeding for resistance to bacterial wilt was initiated in the forage grass breeding programs of the Swiss agricul-

Corresponding author: V. V. Michel

E-mail: vincent.michel@rac.admin.ch

Accepted for publication 6 February 2001.

Publication no. D-2001-0313-03R

(C) 2001 The American Phytopathological Society tural research system shortly after the discovery of its causal agent. Inoculation procedures to screen breeding populations of host plant species were developed in the recurrent breeding scheme used to improve the species, with cycles varying from 2 to 3 years. At the beginning of each new cycle of selection, susceptible host species such as meadow fescue, tall fescue, and Italian rye grass were artificially infected in the greenhouse with a highly aggressive $X$. campestris pv. graminis strain. A single strain was used for inoculation and was replaced by a new isolate once it lost its pathogenicity due to storage on artificial medium (16).

The goals of this study were to compare the aggressiveness of a collection of $X$. campestris pv. graminis strains obtained over a period of two decades and to compare the effect of different strains on a range of meadow fescue and Italian rye grass cultivars. In addition, the progress of resistance breeding was studied on a number of meadow fescue cultivars issued from different cycles of recurrent selection at Changins.

\section{MATERIALS AND METHODS}

Strain aggressiveness experiment. From the collection of $X$. campestris pv. graminis strains established at Changins between 1975 and 1995, 14 strains were selected to compare their aggressiveness (Table 1). Until 1997, all strains, with the exception of strains B-002, B-051, B-052, $\mathrm{B}-053$, and $\mathrm{B}-054$, were stored at $4^{\circ} \mathrm{C}$ on yeast-dextrose-calcium agar (YDCA) slants covered with sterile paraffin oil. In 1997 , all the strains with a designation RI$\mathrm{XXX}$ were grown on YDCA at $27^{\circ} \mathrm{C}$. Sin- gle 48-h-old colonies were then used to inoculate susceptible host plants (i.e., meadow fescue cv. Merifest or Italian rye grass cv. Lutil). The bacterium was reisolated from plants showing typical wilt symptoms. Strains obtained in this way were then multiplied on YDCA and 48-hold colonies were freeze dried in a suspension containing $10 \%$ skim milk and $1.5 \%$ sodium glutamate (T. W. Mew, personal communication). In 1997, the strains designated B-XXX, which already had been stored in freeze-dried form for several years, were recultivated on YDCA and single colonies were directly multiplied and again freeze dried without prior inoculation of host plants. After freeze drying, the vials were closed under vacuum with rubber stoppers and were stored at $4^{\circ} \mathrm{C}$.

Strain aggressiveness was tested on meadow fescue and Italian rye grass. Both plant species are cross-breeders and cultivars are synthetic varieties (i.e., hybrids issued by a restricted number of parental clones; 1). Therefore, the cultivars are phenotypically homogenous populations composed of genetically heterogeneous and heterozygous individuals. To limit the cultivar variation, seeds were stored at $4^{\circ} \mathrm{C}$ in sufficient quantities so that the same seed lot was always used. Seeds of meadow fescue cv. Preval and Italian rye grass cv. Lipurus (Table 2) were sown in a sterile peat substrate in plastic trays ( 50 by $32 \mathrm{~cm}$ in area, $6 \mathrm{~cm}$ in depth). Five rows of each plant species were sown in the same tray. In a first step, meadow fescue was sown and the trays placed in darkness at a constant air temperature of $10^{\circ} \mathrm{C}$, conditions which favor a synchronous germination of this species. After 5 days, trays were transferred to a growth cabinet with air temperature settings of 18 and $12{ }^{\circ} \mathrm{C}$ (day and night, 14-h photoperiod). In a second step, Italian rye grass, which germinates rapidly and synchronously, was sown 8 days after sowing meadow fescue. This difference in sowing dates was needed to synchronize the two species for the inoculation stage (i.e., the three-leaf stage). When seedlings reached this stage, they were transferred to a growth cabinet with air temperature set to 24 and $18^{\circ} \mathrm{C}$ (day and night) until the end of the experiment. The four replicates of one treatment were sown in four different trays, which were arranged in a randomized complete block design in the growth cabinet. Blocks were oriented to compensate for the existing 
temperature gradient caused by the direction of the air flux. Air relative humidity varied between $60 \%$ (day) and $90 \%$ (night). A mixture of florescent tubes and incandescent lamps provided a photosynthetic photon flux density of $200 \mu \mathrm{mol} \mathrm{m} \mathrm{m}^{-2}$ $\mathrm{s}^{-1}$ at pot level, which guaranteed excellent growth of both grass species. Plants were irrigated by pouring water into trays placed below trays containing the plants, allowing the water to be soaked up by the peat substrate. Plants were irrigated three times a week to avoid wilting. No fertilizer was added during the experiments, because the peat substrate was already highly enriched with $\mathrm{N}, \mathrm{P}_{2} \mathrm{O}_{5}$, and $\mathrm{K}_{2} \mathrm{O}$. No plant protection measures were applied during the experiment.

Seedlings were inoculated at the threeleaf stage, which occurred 2 to 3 weeks after sowing. The $X$. campestris pv. graminis strains were multiplied on YDCA medium for $48 \mathrm{~h}$ at $27^{\circ} \mathrm{C}$ and a suspension with sterile distilled water was prepared. For each of the two replicates of the experiment, a new set of freeze-dried strains was used. The suspension was adjusted to a final concentration of $1 \times 10^{9} \mathrm{CFU} / \mathrm{ml}$ on plate count agar (Difco Laboratories, Detroit) using $\mathrm{BaCl}_{2}$ standard suspensions (10) which were previously calibrated for $X$. campestris pv. graminis by dilution plating. All three leaves of each seedling were clipped with a pair of scissors dipped in the bacterial suspension, a method adapted from the procedure to screen rice for resistance to X. oryzae (5). After clipping all seedlings of one row, the scissors were sterilized by flaming them after immersion in $95 \% \mathrm{EtOH}$.

The area under disease progress curve (AUDPC) based on wilt incidence (18) was used to measure the aggressiveness of the $X$. campestris pv. graminis strains. Before inoculation, seedlings with delayed development were discarded and the number of seedlings in the three-leaf stage was assessed. Bacterial wilt was recorded 4, 7, $10,14,18$, and 21 days after inoculation. A plant was counted as wilted when at least one leaf was partially wilted. AUDPC data were subjected to an analysis of variance (ANOVA) assessing four factors: replicate (block), experiment, species, and strain.

Table 1. Origin of Xanthomonas campestris pv. graminis strains

\begin{tabular}{llllll}
\hline & & \multicolumn{2}{c}{ Isolation } & & \\
\cline { 3 - 4 } Strain & Former designation & Year & Country & Freeze-dried since & Experiment \\
\hline B-002 & Xg 726 & 1978 & Switzerland & 1982 & SA \\
B-051 & Xg 1978 & 1978 & Switzerland & 1978 & SA \\
B-052 & Xg 80/4/1 & 1980 & Switzerland & 1982 & SA \\
B-053 & Xg 717 & 1975 & Switzerland & 1977 & SA, SCI \\
B-054 & Xg 81/4/Dg & 1981 & Switzerland & 1982 & SA \\
RI-019 & CFBP2470 & 1984 & France & 1997 & SA \\
RI-026 & Xg 1/93 & 1993 & Switzerland & 1997 & SA, SCI, IC \\
RI-028 & Xg 2/95 & 1995 & Switzerland & 1997 & SA \\
RI-030 & Xg 3/95 & 1995 & Switzerland & 1997 & SA \\
RI-031 & Xg 5/95 & 1995 & Switzerland & 1997 & SA, SCI, IC \\
RI-032 & Xg nonpathogenic c & 1978 & Switzerland & 1997 & SA \\
RI-039 & Xg 4/95 & 1995 & Switzerland & 1997 & SA \\
RI-042 & Xg (La Frétaz) & 1993 & Switzerland & 1997 & SA \\
RI-043 & Xg 2/93 & 1993 & Switzerland & 1997 & SA, SCI \\
Xg 1/93 & & 1993 & Switzerland & Not freeze dried & BP \\
\hline
\end{tabular}

a $\mathrm{SA}=$ strain aggressiveness experiment, $\mathrm{IC}=$ inoculum concentration experiment, $\mathrm{SCI}=$ straincultivar interaction experiment, and $\mathrm{BP}=$ breeding progress experiment.

${ }^{\mathrm{b}} \mathrm{CFBP}=$ Collection française de bactéries phytopathogènes.

${ }^{c}$ Originally strain Xg 726, which lost its pathogenicity after storage on artificial medium.

Table 2. Cultivars of meadow fescue (Festuca pratensis) and Italian rye grass (Lolium multiflorum) used for the experiments

\begin{tabular}{lll}
\hline Species, cultivar & Year of release & \multicolumn{1}{c}{ Origin } \\
\hline F. pratensis & & \\
Arni & 1983 & Jõgeva PBI (Jõgeva, Estonia) \\
Cosmos 11 & 1953 & Saatzucht Steinach (Steinach, Germany) \\
FP6 & Not yet released & RAC (Nyon, Switzerland) \\
Merifest & 1985 & DvP (Melle, Belgium) \\
Pradel & 1998 & RAC (Nyon, Switzerland) \\
Premil & 1993 & RAC (Nyon, Switzerland) \\
Present & 1988 & RAC (Nyon, Switzerland) \\
Preval & 1993 & RAC (Nyon, Switzerland) \\
Pristis & 2000 & RAC (Nyon, Switzerland) \\
L. multiflorum & & \\
Fastyl & 1989 & R.A.G.T. (Rodez, France) \\
Lipo & 1972 & FAL (Zurich, Switzerland) \\
Lipurus & 1995 & FAL (Zurich, Switzerland) \\
Meribel & 1991 & DvP (Melle, Belgium) \\
Turilo & 1976 & FAL (Zurich, Switzerland) \\
\hline
\end{tabular}

Least significant difference (LSD) was used for mean separation (8). The difference between meadow fescue and Italian rye grass inoculated with the same strain was tested with linear contrasts (21).

Inoculum concentration experiment. The effect of five inoculum concentrations was tested on meadow fescue cv. Preval and Italian rye grass cv. Lipurus (Table 2). Plants were sown and grown as described above. Two strains, RI-026 and RI-031 (Table 1), were used to inoculate the seedlings. A stock suspension with a concentration of $1 \times 10^{9} \mathrm{CFU} / \mathrm{ml}$ was prepared and serial dilutions were used to obtain the $1 \times 10^{9}, 1 \times 10^{8}, 1 \times 10^{7}, 1 \times 10^{6}$, and $1 \times$ $10^{5} \mathrm{CFU} / \mathrm{ml}$ used for inoculation. Inoculation and disease assessment was done as previously described. AUDPC data were subjected to ANOVA assessing four factors: replicate (block), species, strain, and concentration. The effect of inoculum concentrations was tested with linear contrasts.

Strain-cultivar interaction experiment. The effect of four selected strains of $X$. campestris pv. graminis on five cultivars of meadow fescue and Italian rye grass was tested in a series of experiments. The two plant species were tested in separate experiments, which were repeated for each species. Per tray, five cultivars could be tested for their resistance to two of the four strains. The selection of strains RI026, RI-031, RI-043, and B-053 (Table 1) was based on the comparisons of the strains but also on their history, including the oldest and most recently isolated and the most and least aggressive strain. The cultivars were issued from four and three different breeding programs for meadow fescue and Italian rye grass, respectively (Table 2). The meadow fescue cultivars were Arni, Cosmos 11, Merifest, Present, and Preval; the Italian rye grass cultivars were Fastyl, Lipo, Lipurus, Meribel, and Turilo. The experiments were conducted as described for the strain aggressiveness experiment, with the exception of the absence of synchronization of the two species. AUDPC data were subjected to ANOVA assessing four factors: replicate (block), experiment, cultivar, and strain. LSD was used for mean separation.

Breeding progress experiment. The progress in breeding of meadow fescue for bacterial wilt resistance was measured by comparing six cultivars originating from the breeding program of Changins. They represented three steps of improvement, differing by two to three cycles of recurrent selection. The first and second generations were formed by the cv. Present and cvs. Premil and Preval, which were released in 1988 and 1993, respectively (Table 2). The third generation was formed by the not yet released cvs. FP6, Pradel, and Pristis. Pradel and Pristis were released in 1998 and 2000, respectively. The repeated experiment was conducted as previously described, with two exceptions. 
First, cultivars were sown in plastic pots (6 by $6 \mathrm{~cm}$ in area, $5 \mathrm{~cm}$ in depth) instead of trays. One cultivar was sown per pot at a rate of 20 seeds per pot, with four replicates. Second, the not-freeze-dried strain $\mathrm{Xg} \mathrm{1/93} \mathrm{(Table} \mathrm{1)} \mathrm{was} \mathrm{used} \mathrm{for} \mathrm{inocula-}$ tion. Between the two experiments, the strain was maintained on YDCA stored at $4^{\circ} \mathrm{C}$. ANOVA of AUDPC data included the factors replicates (block), experiment, and cultivar. To measure the breeding progress of meadow fescue cultivars, linear contrasts were used to compare the different generations of cultivars.

\section{RESULTS}

The aggressiveness of the $14 \mathrm{X}$. campestris pv. graminis strains on meadow fescue and Italian rye grass varied widely (Table 3) and differences between strains were highly significant $(P<0.001)$. Three strains caused no wilt symptoms and were therefore excluded from statistical analysis. Among the most aggressive strains were recently (i.e., since 1993) isolated ones, such as RI-031, as well as B-002, which was isolated more than 20 years ago. Even though most strains had a similar aggressiveness on both plant species $(P=0.086)$, a highly significant interaction between plant species and strain $(P<0.001)$ occurred (Fig. 1).

Each increase of the inoculum by a factor of 10 led to a significantly higher disease progress $(P<0.01)$ between the concentrations $1 \times 10^{5}$ and $1 \times 10^{8} \mathrm{CFU} / \mathrm{ml}$ (Fig. 2). No further significant increase was achieved when the concentration was

Table 3. Area under disease progress curve based on wilt incidence of meadow fescue (cv. Preval) and Italian rye grass (cv. Lipurus) caused by 11 strains of Xanthomonas campestris pv. graminis ${ }^{\mathrm{a}}$

\begin{tabular}{lccc}
\hline Strain $^{\mathbf{b}}$ & $\begin{array}{c}\text { Meadow } \\
\text { fescue }\end{array}$ & $\begin{array}{c}\text { Italian } \\
\text { rye grass }\end{array}$ & Mean $^{\mathbf{c}}$ \\
\hline B-002 & 7.50 & 5.05 & 6.27 \\
B-051 & 3.79 & 2.29 & 3.04 \\
B-053 & 3.03 & 4.77 & 3.90 \\
RI-019 & 6.42 & 5.83 & 6.13 \\
RI-026 & 4.89 & 6.14 & 5.52 \\
RI-028 & 1.89 & 3.38 & 2.63 \\
RI-030 & 3.35 & 7.68 & 5.51 \\
RI-031 & 8.29 & 6.97 & 7.63 \\
RI-039 & 5.73 & 6.45 & 6.09 \\
RI-042 & 4.94 & 5.75 & 5.35 \\
RI-043 & 1.28 & 1.40 & 1.34 \\
LSD (5\%) & $\ldots$ & $\ldots$ & 2.25 \\
\hline
\end{tabular}

${ }^{a}$ Results are means of two experiments run in growth cabinets with highly conducive conditions (i.e., air temperature 24 and $18^{\circ} \mathrm{C}$, day and night, respectively). Wilt incidence was recorded until 21 days after inoculation.

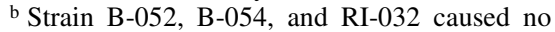
wilt and were excluded from statistical analysis. LSD = least significant difference.

${ }^{c}$ Analysis of variance resulted in no significant difference between plant species $(P=0.086)$, highly significant differences between strains $(P<0.001)$, and highly significant plant species-strain interactions $(P<0.001)$. raised from $1 \times 10^{8}$ to $1 \times 10^{9} \mathrm{CFU} / \mathrm{ml}$. No significant interactions between concentration-plant species and concentration-strain occurred.

The four selected $X$. campestris pv. graminis strains were significantly different $(P<0.001)$ in their aggressiveness on the five cultivars of meadow fescue and Italian rye grass (Fig. 3). Cultivars of both plant species were significantly different $(P<0.001)$ in their resistance to bacterial wilt. Highly significant interactions between strains and cultivars occurred for meadow fescue $(P<0.001)$ but not for Italian rye grass $(P=0.934)$.

An increase in bacterial wilt resistance of meadow fescue cultivars (Table 4) between the first and second step of im- provement was evident because the difference of 3.20 between the AUDPC of cv. Present (first generation) and the average of cvs. Premil and Preval (second generation) was highly significant $(P<0.001)$. In contrast, the increase of resistance between the second and third generation of cultivars was much smaller and the AUDPC difference of 0.42 was not significant $(P=0.54)$.

The replication of the experiments was not significantly different for the strain aggressiveness experiment $(P=0.76)$ and the strain-cultivar interaction experiment with meadow fescue $(P=0.33)$. For the strain-cultivar interaction experiment with Italian rye grass and the breeding progress experiment, a significant difference $(P<$ 0.001 ) between the two replicates of the



Xanthomonas campestris pv. graminis strain

Fig. 1. Area under disease progress curve (AUDPC) based on wilt incidence of meadow fescue (cv. Preval) and Italian rye grass (cv. Lipurus) caused by 11 strains of Xanthomonas campestris pv. graminis. Data presented are means of two experiments run in growth cabinets with highly conducive conditions (i.e., air temperature 24 and $18^{\circ} \mathrm{C}$, day and night, respectively). Wilt incidence was recorded until 21 days after inoculation. Analysis of variance resulted in no significant difference between plant species $(P=0.086)$, highly significant differences between strains $(P<0.001)$, and highly significant plant species-strain interactions $(P<0.001)$. Differences indicated between plant species are based on linear contrast (ns: $P>0.05$ ).

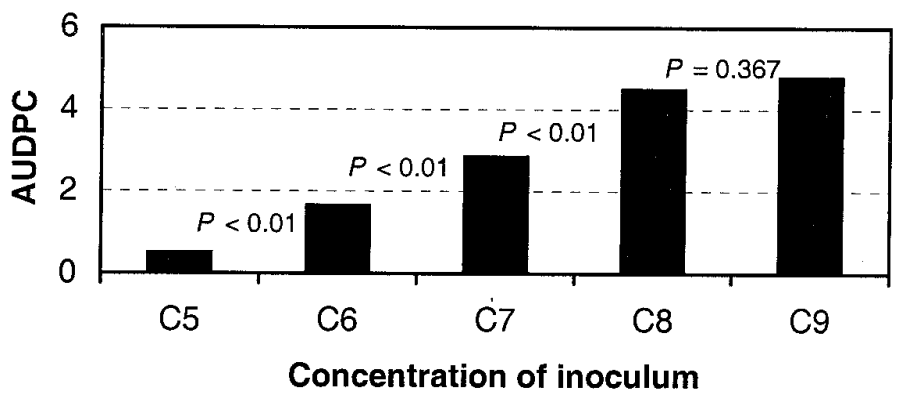

Fig. 2. Area under disease progress curve (AUDPC) based on wilt incidence after inoculation with five concentrations, C5, C6, C7, C8, and C9, corresponding to $1 \times 10^{5}, 1 \times 10^{6}, 1 \times 10^{7}, 1 \times 10^{8}$, and $1 \times 10^{9} \mathrm{CFU} / \mathrm{ml}$, respectively. Data presented are means of two species, meadow fescue (cv. Preval) and Italian rye grass (cv. Lipurus), and two strains of Xanthomonas campestris pv. graminis, RI-026 and RI-031, tested in one experiment. Wilt incidence was recorded until 21 days after inoculation. Analysis of variance resulted in highly significant differences between concentrations $(P<0.001)$, plant species $(P<0.001)$, and strains $(P<0.001)$. No significant interactions between concentrations and strains, concentrations and plant species, or plant species and strains occurred. 
experiments existed, but no significant interactions between the factor experiment and the other factors tested (i.e., strain and cultivar) occurred.

\section{DISCUSSION}

The wide range of aggressiveness of $X$. campestris pv. graminis reflects the endemic nature of the pathogen and wide range of host plants, which includes sev- eral genera of the Poaceae family (3). Highly aggressive strains apparently are not the result of selection on resistant forage grass cultivars, as indicated by strain B-002, which was isolated in 1978 and had a level of aggressiveness similar to the strains RI-031 and RI-039 isolated in 1995. Among the strains tested are two screening strains used for resistance breeding in Switzerland (i.e., B-002 and RI-026). The
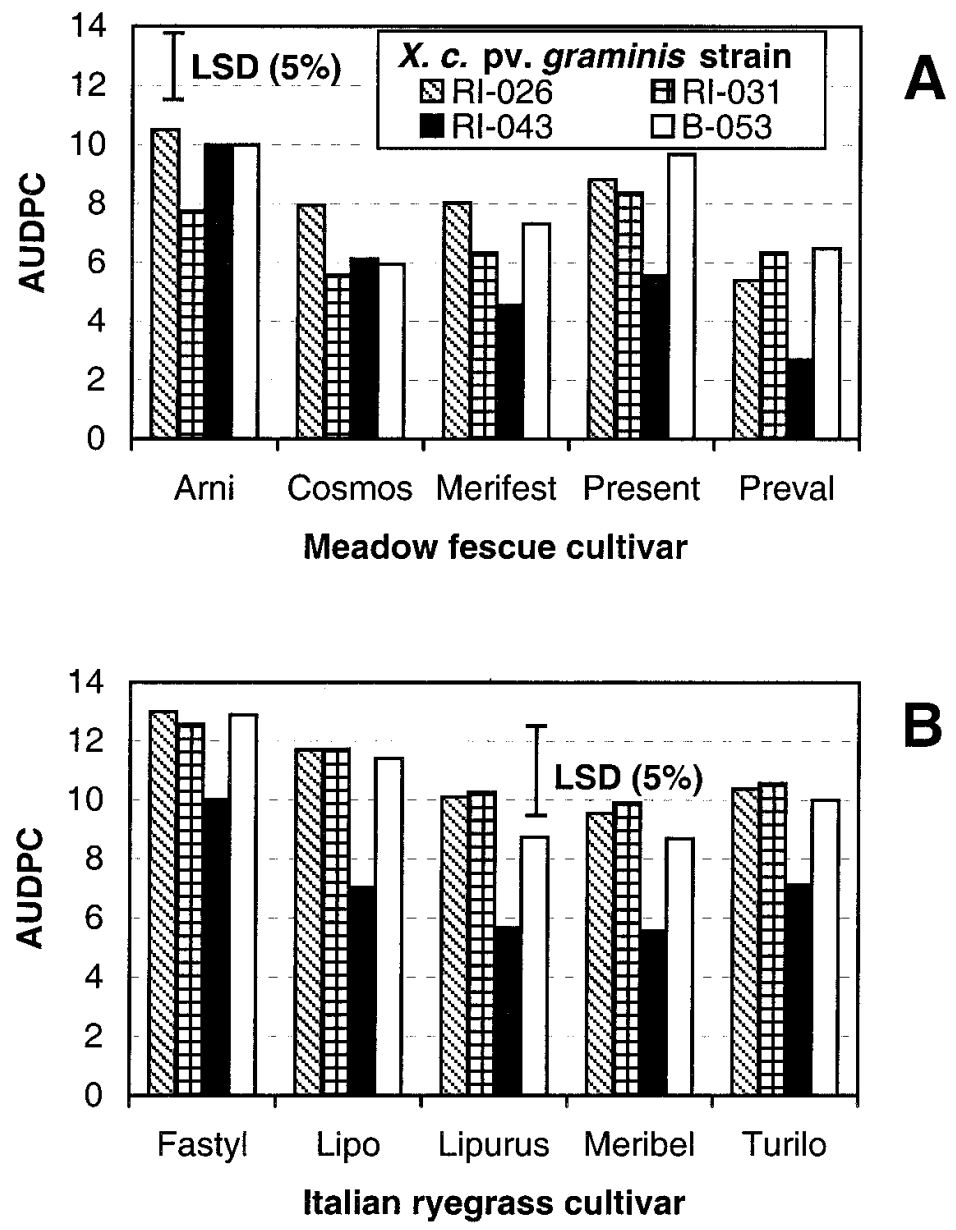

Fig. 3. Area under disease progress curve (AUDPC) based on wilt incidence of A, five meadow fescue cultivars and B, five Italian rye grass cultivars caused by four strains of Xanthomonas campestris pv. graminis. Data presented are means of two experiments run separately for the two plant species in growth cabinets with highly conducive conditions (i.e., air temperature 24 and $18^{\circ} \mathrm{C}$, day and night, respectively). Wilt incidence was recorded until 21 days after inoculation. Analysis of variance resulted for both species in highly significant differences between cultivars $(P<0.001)$ and strains $(P$ $<0.001)$. Highly significant interactions between strains and cultivars occurred for meadow fescue $(P$ $<0.001)$ but not for Italian rye grass $(P=0.934)$.

Table 4. Area under disease progress curve (AUDPC) based on wilt incidence of six meadow fescue cultivars released by the forage grass improvement program of Changins ${ }^{a}$

\begin{tabular}{lcccc}
\hline Cultivar & AUDPC & Generation & \multicolumn{2}{c}{ Linear contrasts } \\
\hline Present & 12.91 & 1 & +2 & 0 \\
Premil & 11.20 & 2 & -1 & +3 \\
Preval & 8.21 & 2 & -1 & +3 \\
Pristis & 8.76 & 3 & 0 & -2 \\
Pradel & 12.25 & 3 & 0 & -2 \\
FP6 & 6.86 & 3 & 0 & -2 \\
Probability $>F$ & 0.001 & $>|t|$ & 0.0011 & 0.54 \\
\hline
\end{tabular}

${ }^{a}$ Results are means of two experiments run in growth cabinets with highly conducive conditions (i.e., air temperature $24 / 18^{\circ} \mathrm{C}$ day/night). Wilt incidence was recorded until 21 days after inoculation with Xanthomonas campestris pv. graminis strain Xg 1/93.

replacement of these strains based only on their aggressiveness is not justified because they both show a similar level when maintained in freeze-dried form. In fact, the replacement of B-002 was due to the loss of pathogenicity when maintained on artificial medium (20). After this loss, it was used as a nonpathogenic strain for a series of experiments (16) and was included as strain RI-032 in the collection from Changins. Similar losses of pathogenicity probably happened to strains B-052 and B054 before their freeze drying, which would explain their nonpathogenicity in the present study.

Using a single strain for resistance screening is a widespread technique. One of the reasons is that resources are limited, especially in smaller breeding programs, where the breeder also assumes pathological tasks. This reduces the evaluation of the variation of a given pathogen and the maintenance of a larger culture collection. Another reason might be the success of this kind of screening when released cultivars are mainly used on a regional scale. The application of a single strain to screen for bacterial wilt resistance in meadow fescue proved to be highly effective in the beginning of resistance breeding at Changins. The stagnation in breeding progress in a later stage may be due to several factors. The decrease of improvement for a breeding trait after an initial phase of fast progress is a known phenomena (9). Breeding for a specific trait is complicated when an increasing number of traits need to be improved simultaneously (19). In the case of the meadow fescue improvement program of Changins, breeding goals are high dry matter yield, ability to compete with other plant species (for use in species mixtures), persistence, and increased resistance to $X$. campestris pv. graminis, Bipolaris sorokiniana (causal agent of leaf spot), Fusarium culmorum (causal agent of seedling blight), and Puccinia coronata (causal agent of crown rust).

The disease progress curves used to measure the aggressiveness of the $X$. campestris pv. graminis strains clearly depended upon the inoculum concentration. Together with the variation in aggressiveness of the strains, an adjustment of the disease pressure during the screening process should be possible. Such a combination proved to be useful for the screening of Kentucky blue grass for its resistance to Drechslera poae, causal agent of melting out disease (11). However, combining inoculum concentration with strain aggressiveness has to be applied with care because of interactions between $X$. campestris pv. graminis strains and plant species and, even more important, between the cultivars within meadow fescue. Strains of Ralstonia solanacearum, the causal agent of bacterial wilt of tomato (Lycopersicon esculentum), were reported to vary in their aggressiveness even when 
isolated from a small geographic area (13). This variation of aggressiveness was most probably the reason for a breakdown of resistance of tomato lines which were highly resistant in Taiwan but susceptible in the Philippines and Indonesia (4).

Variation of aggressiveness of $X$. campestris pv. graminis clearly occurred on meadow fescue and Italian rye grass. Of the 11 strains used, 10 were isolated in Switzerland, indicating a significant variation for aggressiveness at a regional level. A very high genotypic diversity of Phaeosphaeria nodorum, causal agent of wheat glume blotch, within field populations was reported recently (6). Among the field populations that originated from Oregon, Texas, and Switzerland, genotypic diversity based on DNA fingerprints reached the highest value of $100 \%$ in Swiss populations. The high degree of genetic diversity of pathogens in Switzerland, which is expressed for $X$. campestris pv. graminis in its variation of aggressiveness, might be explained by the country's different ecological environments distributed over a small geographic scale. In the case of the forage grass-bacterial wilt pathosystem, natural grasslands, covering more than $72 \%$ of the agriculturally used land (2), form an important reservoir of host plants and therefore are a source for pathogen diversity. Strain RI-042, for example, was initially isolated at La Frêtaz, the mountain research domain attached to the research station Changins, which is situated at 1,202 $\mathrm{m}$ above sea level in a typical mountainous grassland area.

The availability of $X$. campestris pv. graminis strains with different levels of aggressiveness in Switzerland allows the testing of breeding material without the use of exotic strains. The exclusion of exotic strains of pathogens in a crop improvement program is of major importance because many breeding activities are done in the field, which makes the spread of most pathogens to the surrounding areas unavoidable. It may also help to avoid the breakdown of resistance once the cultivars are used outside the region where they were originally released. Meadow fescue cvs. Arni and Preval were equally resistant to strain RI-031. In contrast, when inoculated with strain RI-026, Arni was much more susceptible than Preval. Therefore, the use of a mixture of $X$. campestris pv. graminis strains to improve meadow fescue has to be considered indispensable to guarantee a success of Swiss cultivars when commercialized on a larger geographic scale, such as in Western and Northern European countries.

\section{ACKNOWLEDGMENTS}

I thank S. Amiguet, F. Esteban, and S. Kellenberger for their technical assistance; and B. A. McDonald, D. Pellet, and A. Schori for their comments concerning the manuscript. Finally, I dedicate this publication to D. Schmidt for all her excellent research in the past and all her knowledge that she transmitted to me.

\section{LITERATURE CITED}

1. Allard, R. W. 1960. Principles of Plant Breeding. John Wiley and Sons, New York.

2. Anonymous. 1998. Statistische Erhebungen und Schätzungen über Landwirtschaft und Ernährung 1998. Schweizerischer Bauernverband, Brugg, Switzerland.

3. Egli, T., Goto, M., and Schmidt, D. 1975. Bacterial wilt, a new forage grass disease. Phytopathol. Z. 82:111-121.

4. Hanson, P. M., Wang, J. F., Licardo, O., Hanudin, Mah, S. Y., Hartman, G. L., Lin, Y. C., and Chen, J. T. 1996. Variable reaction of tomato lines to bacterial wilt evaluated at several locations in Southeast Asia. HortScience 31:143-146.

5. Kauffman, H. E., Reddy, A. P. K., Hsieh, S. P., and Merca, S. D. 1973. An improved technique for evaluating resistance of rice varieties to Xanthomonas oryzae. Plant Dis. Rep. 57:537-541.

6. Keller, S. M., McDermott, J. M., Pettway, R. E., Wolfe, M. S., and McDonald, B. A. 1997. Gene flow and sexual reproduction in the wheat glume blotch pathogen Phaeosphaeria nodorum (anamorph Stagonospora nodorum). Phytopathology 87:353-358.

7. Leyns, F., De Cleene, M., Van Bogaert, G., Van de Wiele, A., and De Ley, J. 1988. Preliminary investigations about the mode of transmission and spread of Xanthomonas campestris pv. graminis on forage grasses. J.
Phytopathol. 122:76-88.

8. Little, T. M., and Hills, F. J. 1978. Agricultural Experimentation. John Wiley and Sons, New York.

9. Mayo, O. 1980. The Theory of Plant Breeding. Clarendon Press, Oxford, U.K.

10. McFarland, J. 1907. The nephelometer: an instrument for estimating the members of bacteria in suspensions used for calculating the opsonic index and for vaccines. J. Am. Med. Assoc. 49:1176.

11. Michel, V. V., and Schori, A. 1998. Optimising disease pressure of Drechslera poae for Kentucky bluegrass (Poa pratensis) screening. Pages 209-211 in: Breeding for a Multifunctional Agriculture. Proc. 21st Meet Fodder Crops Amenity Grasses Sect. EUCARPIA. B. Boller and F. J. Stadelmann, eds. Kartause Ittingen, Switzerland.

12. Paul, V. H., and Smith, I. M. 1989. Bacterial pathogens of Gramineae: Systematic review and assessment of quarantine status for the EPPO region. EPPO Bull. 19:33-42.

13. Prior, P., Steva, H., and Cadet, P. 1990. Aggressiveness of strains of Pseudomonas solanacearum from the French West Indies (Martinique and Guadeloupe) on tomato. Plant Dis. 74:962-965.

14. Schmidt, D. 1988. Le flétrissement bactérien des graminées fourragères: essais pour limiter la dispersion de la maladie lors du fauchage. Rev. Suisse Agric. 20:351-357.

15. Schmidt, D. 1989. Breeding for resistance to bacterial wilt of grasses (Xanthomonas campestris pv. graminis). Pages 717-718 in: XVI Int. Grassland Congr. R. Jarrige, ed. Nice, France.

16. Schmidt, D. 1989. Experiments with a nonpathogenic strain of Xanthomonas campestris pv. graminis. EPPO Bull. 19:143-147.

17. Schmidt, D., and Nüsch, B. 1980. Resistance to bacterial wilt (Xanthomonas graminis) increases yield and persistency of Lolium multiflorum. EPPO Bull. 10:335-339.

18. Shaner, G., and Finney, R. E. 1977. The effect of nitrogen fertilization on the expression of slow-mildewing resistance in Knox wheat. Phytopathology 67:1051-1056.

19. Simmonds, N. W. 1983. Strategy of disease resistance breeding. FAO Plant Prot. Bull. 31:2-10.

20. Stead, D. E. 1990. Preservation of bacteria Pages 275-278 in: Methods in Phytobacteriology. Z. Klement, K. Rudolph, and D. C. Sands, eds. Akadémiai Kiadó. Budapest, Hungary.

21. Swallow, W. H. 1984. Those overworked and oft-misused mean separation proceduresDuncan's, LSD, etc. Plant Dis. 68:919-921. 